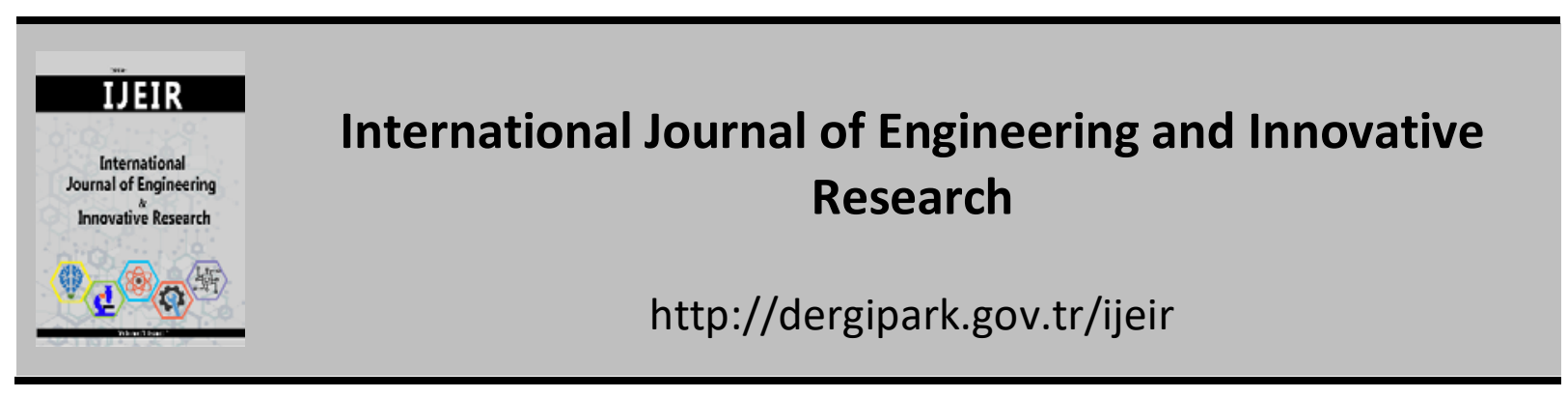

\title{
DESIGN AND SIMULATION OF AN ON-GRID PHOTOVOLTAIC SYSTEM
}

\author{
Wofuru Innocent $^{1^{*}(\mathbb{D})}$, Ekom Abasi Ikoiwak ${ }^{1}$ (D) , Big-Alabo Ameze $^{1}$ (D) \\ ${ }^{1}$ University of Port Harcourt Choba, Faculty of Engineering, Department of Electrical/Electronic Engineering, \\ P.M.B 5323, Rivers State. Nigeria. \\ "Sorumlu Yazar: wofurui@yaho.com \\ https://doi.org/10.47933/ijeir.758978
}

(Received: 07.06.2020; Accepted: 24.08.2020)

\begin{abstract}
In this paper, the design and simulation of an On-grid photovoltaic system for the faculty of Engineering, Abuja campus, University of Port Harcourt (Latitude: $4.78^{\circ} \mathrm{S}$, Longitude: $7.01^{\circ} \mathrm{E}$ ) was researched inorder to verify alternate power source possibility that can supplement for the inconsistent power from the (Power holding company of Nigeria) grid to the faculty. The system Solar modules are mounted in a fixed tilt orientation in 4-parallel strings of 15 Solar panels in series on the roof-top of the faculty. The photovoltaic system is also designed with a two - parallel string of nine Tesla Powerwall batteries in series for the battery bank storage system. Inverters used for this system are two $9.9 \mathrm{~kW}$ battery-based grid-tied inverters stacked in parallel with an inbuilt Maximum power point tracker (MPPT). The reinjection system is on-grid as a net-meter is not used since the Power Holding Company of Nigeria, PHCN does not support Net- metering. Thus, power is not injected into the grid from the solar photovoltaic system. In solving the faculty’s power lapses and improving power supply quality in the faculty, data collected both within the faculty. These methods include data collection, evaluation of load data, data analysis, suitable design adoption, simulation of data. A solar photovoltaic software application package called PVsyst was employed for various simulations and plots. The end simulation and final work prove the system to be $57 \%$ efficient in performance.
\end{abstract}

Keywords: MPPT, PVsyst, solar, On-grid photovoltaic

\section{INTRODUCTION}

Renewable energy biggest source on earth so far known to man is the sun. The sun's energy is harvested utilizing a concentrated power system. Photovoltaics directly convert the sun's energy to electrical energy by photovoltaic effect principle. Free electrons are released when certain materials gain light exposure, absorbing photons. This is a photoelectric effect phenomenon. The photovoltaic effect only exists on the photoelectric effect principle. Thus, solar cells are made from this principle. They convert sunlight to direct current (DC) electricity. [6] Single photovoltaic cell does not produce enough electricity as such, a passable number of photovoltaic cells are mounted on a supporting frame, connected electrically to form a photovoltaic module or solar panel. Solar panels or modules specifically designed, supply electric power at a certain potential with produced current indigent on incident light. It is clear that photovoltaic modules produce DC but occasionally we require alternating current, AC. Thus, an inverter and other solar PV components combinations are needed to attain this. [5] Solar energy describes energy amassed from the sun. A complimentary, infinite, inexhaustible, and pollution-free energy. 
The energy created when solar radiation is converted to heat(thermal) and electricity(electric). The strength and effect of sun irradiance differ with a change in atmospheric conditions, time of day, latitude, the position and inclination of the earth concerning the sun. [1]

\section{MATERIAL AND METHODS}

The system designed is to be an on-grid photovoltaic system configuration with back-up batteries with a fixed tilt orientation. The is no solar power injected into the grid since our utility company, PHCN does not support net metering. [8] Hence, the system has no net meter in its system design. System arrangement will constitute PV solar modules 4-parallel strings of 15modules in series. The array is then tethered to the battery bank via the battery charger which acts as a regulator, automatically disconnects the battery bank from the PV array when the battery is full and also regulates the depths of the battery undercharging. [8] The battery bank is then tethered to two $9.9 \mathrm{~kW}$ grid-tied inverters which are connected in parallel to increase its power (watts), then to the critical load panel (where the appliance for PV system are all connected). The critical load panel draws specific loads from the building's mains distribution panel and gets isolated from all other loads. [8]

\subsection{Software Selection}

Numerous Solar PV Software such as heliostat, PVsol, PVsyst were sampled. The decision to adopt the PVsyst software was made based on its reviews, frequency of use by researchers outside Nigeria to design solar systems, simplicity, less complexity and ease of learning than that of other software, ease of accessibility, accuracy, allows for proper calculation of load values and more. PVsyst V6.8.4 is a solar PC software for PV system sizing, design, and analysis. The software contains substantial timely meteorological fact and solar components database. It offers three different configurations of PV system study namely: the gridconnected, Off-grid, and pumping system for the development of an actual solar project. The software permits the export of data from external sources such as google map, simulates values in form tables and graphs of the actual performance of system components. [9]

\subsection{Photovoltaic Component Sizing}

First and foremost, daily average solar irradiance on horizontal surfaces in Port Harcourt which is measured at $4.04 \mathrm{kWh} / \mathrm{m} 2 /$ day. It has been found the panel generation factor of the location to which the PV system will be installed. This factor varies with the variation of the site and has no unit.[11] The daily solar radiation for the location in which the PV plant is sited is divided by the irradiance value of the photovoltaic module at STC. For Port Harcourt city the daily average irradiance value is $4.04 \mathrm{kWh} / \mathrm{m} 2 /$ day.

The following formula applies: -

$$
\begin{aligned}
\text { Panel Generation Factor } & =\frac{\text { Daily Solar Radiation of Location }}{\text { Irradiance of PV at STC }} \\
& =\frac{4.04 \times 10^{3}}{1000}=4.04 .
\end{aligned}
$$

The total PV panel energy required is multiplied against the system losses compensation factor known to be a constant of 1.3. Recall that Total energy consumption of appliances, 
$=60,212 \mathrm{Whr} /$ day $\quad$ or $=60.212 \mathrm{kWh} /$ day.

Energy lost in system $=1.3$.

Total PV module energy required= $($ Energy Consumption $\times$ Energy lost in the system $)$.

$$
=60.212 \mathrm{kWhr} / \text { day } \times 1 .=78925.6 \mathrm{Whr} / \mathrm{day}
$$

\subsubsection{PV system module sizing.}

To size, the PV modules, the total watt peak rating required to operate the PV modules was first determined. The Formula implies

$$
\mathrm{P}_{\mathrm{pv}}=\frac{\mathrm{E}_{\mathrm{d}}}{(\mathrm{PSH}) \times \eta_{\mathrm{CR}} \times \eta_{\mathrm{inv}}}
$$

where is the daily energy consumption of the faculty in $\mathrm{kWh} /$ day, PSH is the peak sunshine hours (hrs/day), is the charge regulator efficiency, and is the inverter efficiency. For simplification, the formula below is adopted.

Total watt peak of PV modules $=\frac{\text { Energy PVmodules }}{\text { Panel Generation Factor }}$

$$
=\frac{78275.6}{4.04}=19536.0 \mathrm{Wp} .=19536.0 \mathrm{Wp} \text {. }
$$

Using the manufacturer's specification, the PV module peak power rated output was obtained and used to calculate system requirements for the number of modules. The modules' peak power is then divided by the panel generation factor PGF. Solar panels with $330 \mathrm{Wp}$ rated output are chosen for the design. Then the number of pf PV modules require then becomes: -

No. of modules required $=\frac{\text { Total watt peak for PV modules }}{\text { PVmodule peak rated output }}$

$$
=\frac{19536.0}{330}=59.2 \text { modules }
$$

There are no '.2' modules in the PV module industry thus, the next whole number is chosen, which becomes 60 modules. System configuration will show 60 units of solar panels of 330watts capacity adopted for design. The system will perform better with the 60 modules than 59 modules since more PV modules indicate better system performance and fewer PV modules, the system may not work properly and the battery life cut short. [3,4]

\subsubsection{PV system battery sizing.}

Battery capacity required is known as Ampere-hour (Ah). The total ampere-hour can be obtained using the following formula:

$$
C_{\mathrm{BAH}}=\frac{\mathrm{E}_{\mathrm{db}} \times \mathrm{AD}}{\mathrm{DOD} \times \eta_{\mathrm{BAH}} \times V_{\mathrm{B}}}
$$


Where is the daily energy required from the battery, DOD is the permissible depth of discharge, $\mathrm{AD}$ is autonomy days, is the ampere-hour efficiency of the battery cell, and is the selected nominal DC voltage of the battery block $[2,10]$. The values of the factors considered while calculating for battery size are battery loss 0.85 , 4-days of autonomy, depths of discharge, DOD -0.8 , and battery's nominal voltage. From our battery specification, the nominal voltage is $50.4 \mathrm{~V}$. With a similar but simplified calculation, we calculate as follows:

Required battery capacity,

$$
\begin{aligned}
& (\mathrm{Ah})=\frac{\text { Total Whr per day used by appliance } \times \text { Days of Autonomy }}{\text { Battery loss } \times \text { depth of discharge } \times \text { nominal battery voltage }} \\
& =\frac{19536.0 \times 4}{0.85 \times 0.8 \times 50.4}=\frac{78144}{34.2}==2284.9 \mathrm{Ah}
\end{aligned}
$$

Therefore, the total number of batteries for the PV system was found by dividing the required battery capacity by that of 1-battery.

$$
\begin{aligned}
& \text { No of Batteries }=\frac{\text { Required battery capacity }}{\text { Capcity of } 1 \text {-battery }}=\frac{2284.9}{134} \\
& =17.05 \text { batteries } \sim 18 \text {-batteries. }
\end{aligned}
$$

\subsubsection{PV system inverter sizing}

To allow for safe and efficient operation the general rule of thumb is that, size of the inverter should be similar to DC rating of solar panel system or solar generator. Therefore, the inverter sizing calculation is: -

Total watts of all appliances $=20,788 \mathrm{~W}$

Inverter rating $=20,788 \mathrm{~W}$

\subsubsection{Combiner box sizing}

The size of fuse to use is always determined by the datasheet of the panel. For the grid-tied panel, under 300watts a 15A fuse is usually used. For this PV system, solar panel rating is greater than 300 watts therefore, the size of the fuse is calculated as:

Size of Fuse $=$ Solar Panel's Isc x 1.56

$$
=16.302 \mathrm{~A}
$$

The D.C combiner/disconnect box for this system will have 4-16A or 17A fuses to account for the four solar module parallel strings in our design.

\section{PV SYSTEM SIMULATION PERFORMANCE}

The system's simulation performance considers the system sizing and design, the PV system power generated plus the energy stored in the battery block are used to cover the load demand 
when power from PHCN is not available. During the period of grid availability, its power will be used to cover the load demand and to charge the battery block depending on its state of charge. For hourly steps, the simulation software compares the energy demand and the PV energy generated, and according to the difference, the decision to charge or discharge the battery is made. The simulation software takes into cognizance the three following cases for system performance.

First Case: Sufficient energy is being generated by the PV generator array covering the load demand by PV energy will have the priority of charging the battery.

Second Case: the generated PV power is not sufficient to supply the load. The priority here is to utilize grid power if it is available. If grid power is not available, the required load energy is discharged from the battery block.

Third Case: The PV power generated is not sufficient to cover the load and the batteries state of charge, SOC is low. The grid power automatically charges the battery block and covers the load demand at the same time. There is certainty that the grid cut off periods are time-wise irregular depending on the situation with the PHCN and its Distribution companies. Hence the simulation considers the PV system as a standalone system which is the worst-case scenario.

\section{RESULTS AND DISCUSSION}

Table: 1 refers to the summary of the major parameters, its associated equations and values employed in the design of the design and simulation of an on-grid photovoltaic system An efficient on-grid photovoltaic system is designed and simulated. The results of discrete components, their behavior, and that of the complete model are shown and explained from the software.

Table 1. Parameter used in design and its values.

\begin{tabular}{|c|c|c|}
\hline Parameters & Equations & Values \\
\hline Panel Generation Factor & $\frac{\text { Daily Solar Radiation of Location }}{\text { Irradiance of PV at STC }}$ & 4.04 \\
\hline Total PV module energy required & Energy Consumption $\times$ Energy lost in the system & 78925 \\
\hline Total watt peak of PV modules & $\frac{\text { Energy PVmodules }}{}$ & 19536.0Wp. \\
\hline No. of modules required & $\frac{\text { Total watt peak for PV modules }}{\text { PVmodule peak rated output }}$ & 59.2 \\
\hline Required battery capacity & $\frac{\text { Total Whr per day used by appliance } \times \text { Days of Autonomy }}{\text { Battery loss } \times \text { depth of discharge } \times \text { nominal battery voltag }}$ & \\
\hline No of Batteries & $\frac{\text { Required battery capacity }}{\text { Capcity of } 1-\text { battery }}$ & 18 \\
\hline Size of Fuse & = Solar Panel's Isc x 1.56 & $16.302 \mathrm{~A}$ \\
\hline
\end{tabular}




\begin{tabular}{|c|c|c|c|c|c|}
\hline Site & Port Harc & ourt (Nige & ria) & & \\
\hline \multirow[t]{2}{*}{ Data source } & Meteonorm & 7.1 & & & \\
\hline & $\begin{array}{l}\text { Global Irrad. } \\
\mathrm{kWh} / \mathrm{m}^{2} \text {.day }\end{array}$ & $\begin{array}{l}\text { Diffuse } \\
\mathrm{kWh} / \mathrm{m}^{2} \text {.day }\end{array}$ & Temper. & $\begin{array}{l}\text { Wind Vel. } \\
\mathrm{m} / \mathrm{s}\end{array}$ & \multirow{6}{*}{$\begin{array}{l}\text { Required Data } \\
\nabla \text { Horizontal global irradiation } \\
\nabla \text { Average Ext. Temperature }\end{array}$} \\
\hline January & 4.22 & 2.82 & 27.4 & 0.99 & \\
\hline February & 4.39 & 2.76 & 28.2 & 1.19 & \\
\hline March & 4.35 & 3.05 & 28.0 & 1.30 & \\
\hline April & 4.37 & 2.85 & 27.0 & 1.20 & \\
\hline May & 4.22 & 2.73 & 27.2 & 1.19 & \\
\hline June & 3.89 & 2.71 & 25.8 & 1.19 & Extra data \\
\hline July & 3.56 & 2.47 & 25.6 & 1.20 & $\sqrt{\nabla}$ Horizontal diffuse irradiation \\
\hline August & 3.36 & 2.34 & 24.9 & 1.30 & $\sqrt{\checkmark}$ Wind velocity \\
\hline September & 3.88 & 2.43 & 25.1 & 1.20 & Irradiation units \\
\hline October & 3.97 & 2.43 & 26.1 & 1.19 & $6 \mathrm{kWh} / \mathrm{m}^{2}$.day \\
\hline November & 4.06 & 2.54 & 26.4 & 1.08 & $C \mathrm{kWh} / \mathrm{m}^{2} \cdot \mathrm{mth}$ \\
\hline December & 4.24 & 2.71 & 27.4 & 0.99 & $\curvearrowright \mathrm{MJ} / \mathrm{m}^{2}$.day \\
\hline Year & 4.04 & 2.65 & 26.6 & 1.2 & $\mathrm{CMJ} / \mathrm{m}^{2} \cdot \mathrm{mth}$ \\
\hline ? & Paste & Paste & Paste & Paste & $C$ Clearness Index Kt \\
\hline
\end{tabular}

Figure 1. Daily Global Site Irradiance \& Temperature Values/Day.

In Figure1, the solar global irradiation of the Faculty per day for the 12-months of the year is generated using the meteonorm 7.1 data site. It shows the average global irradiance as $4.04 \mathrm{kWh} / \mathrm{m} 2$.day while diffused irradiance is at $2.65 \mathrm{kWh} / \mathrm{m} 2$.day. The average temperature at $26.60 \mathrm{C}$ and wind velocity at $1.2 \mathrm{~m} / \mathrm{s}$.

\begin{tabular}{|c|c|c|c|c|c|}
\hline Site & \multicolumn{4}{|c|}{ Port Harcourt [Nigeria] } & \\
\hline \multirow[t]{2}{*}{ Data source } & Meteonorm & 7.1 & & & \\
\hline & $\begin{array}{l}\text { Jlobal Irrad. } \\
\mathrm{kW} / \mathrm{m}^{2} . \mathrm{mth}\end{array}$ & $\begin{array}{l}\text { Diffuse } \\
k^{W} / \mathrm{m}^{2} \cdot \mathrm{mth}\end{array}$ & Temper. & $\begin{array}{l}\text { W/ind Vel. } \\
\mathrm{m} / \mathrm{s}\end{array}$ & \multirow{6}{*}{$\begin{array}{l}\text { Required Data } \\
\nwarrow \checkmark \text { Horizontal global irradiation } \\
\nwarrow \checkmark \text { Average Ext. Temperature }\end{array}$} \\
\hline January & 130.7 & 87.3 & 27.4 & 0.99 & \\
\hline February & 122.8 & 77.4 & 28.2 & 1.19 & \\
\hline March & 135.0 & 94.7 & 28.0 & 1.30 & \\
\hline April & 131.2 & 85.5 & 27.0 & 1.20 & \\
\hline May & 130.7 & 84.7 & 27.2 & 1.19 & \\
\hline June & 116.6 & 81.4 & 25.8 & 1.19 & \multirow{3}{*}{$\begin{array}{l}\text { Extra data } \\
\sqrt{\checkmark} \text { Horizontal diffuse irradiation } \\
\sqrt{\checkmark} \text { Wind velocity }\end{array}$} \\
\hline July & 110.5 & 76.5 & 25.6 & 1.20 & \\
\hline August & 104.2 & 72.6 & 24.9 & 1.30 & \\
\hline September & 116.3 & 73.0 & 25.1 & 1.20 & \multirow{6}{*}{ 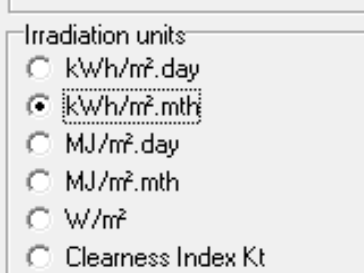 } \\
\hline October & 123.1 & 75.4 & 26.1 & 1.19 & \\
\hline November & 121.7 & 76.3 & 26.4 & 1.08 & \\
\hline December & 131.5 & 84.1 & 27.4 & 0.99 & \\
\hline Year & 1474.3 & 968.9 & 26.6 & 1.2 & \\
\hline$?$ & Paste & Paste & Paste & Paste & \\
\hline
\end{tabular}

Figure 2. Daily Site Irradiance \& Temperature Values/Month.

In Figure 2, the global irradiation of the Faculty per month for the 12-months of the year is generated using the meteonorm 7.1 data site. It shows the average global irradiance per month to be as $1474.3 \mathrm{kWh} / \mathrm{m} 2 . \mathrm{mth}$ whilst diffused irradiance is at $968.9 \mathrm{kWh} / \mathrm{m} 2 . \mathrm{mth}$, average 
temperature, and wind velocity correlative to global irradiation per day at $26.60 \mathrm{C}$ and $1.2 \mathrm{~m} / \mathrm{s}$ respectively.

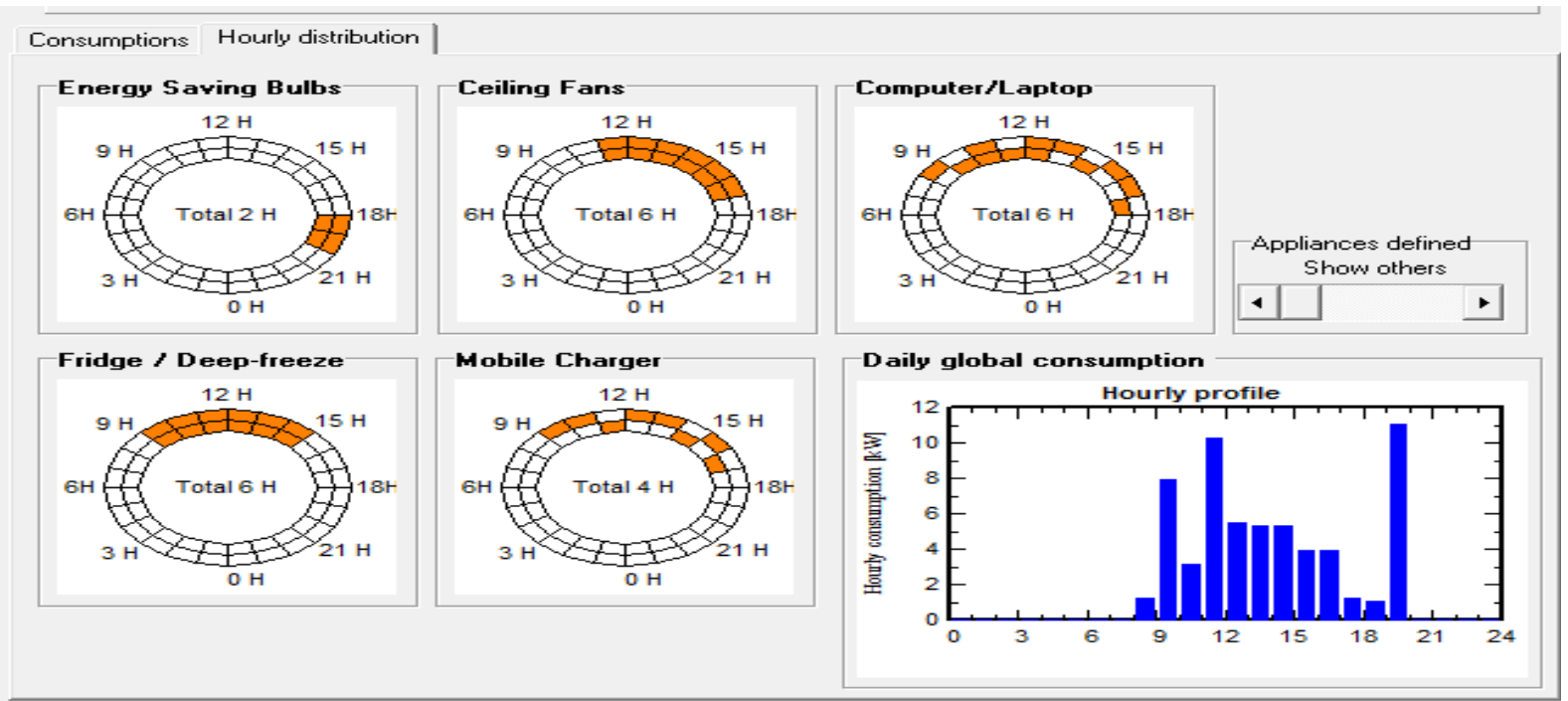

Figure 3. Hourly Load Distribution.

\section{Consumptions Hourly distribution}
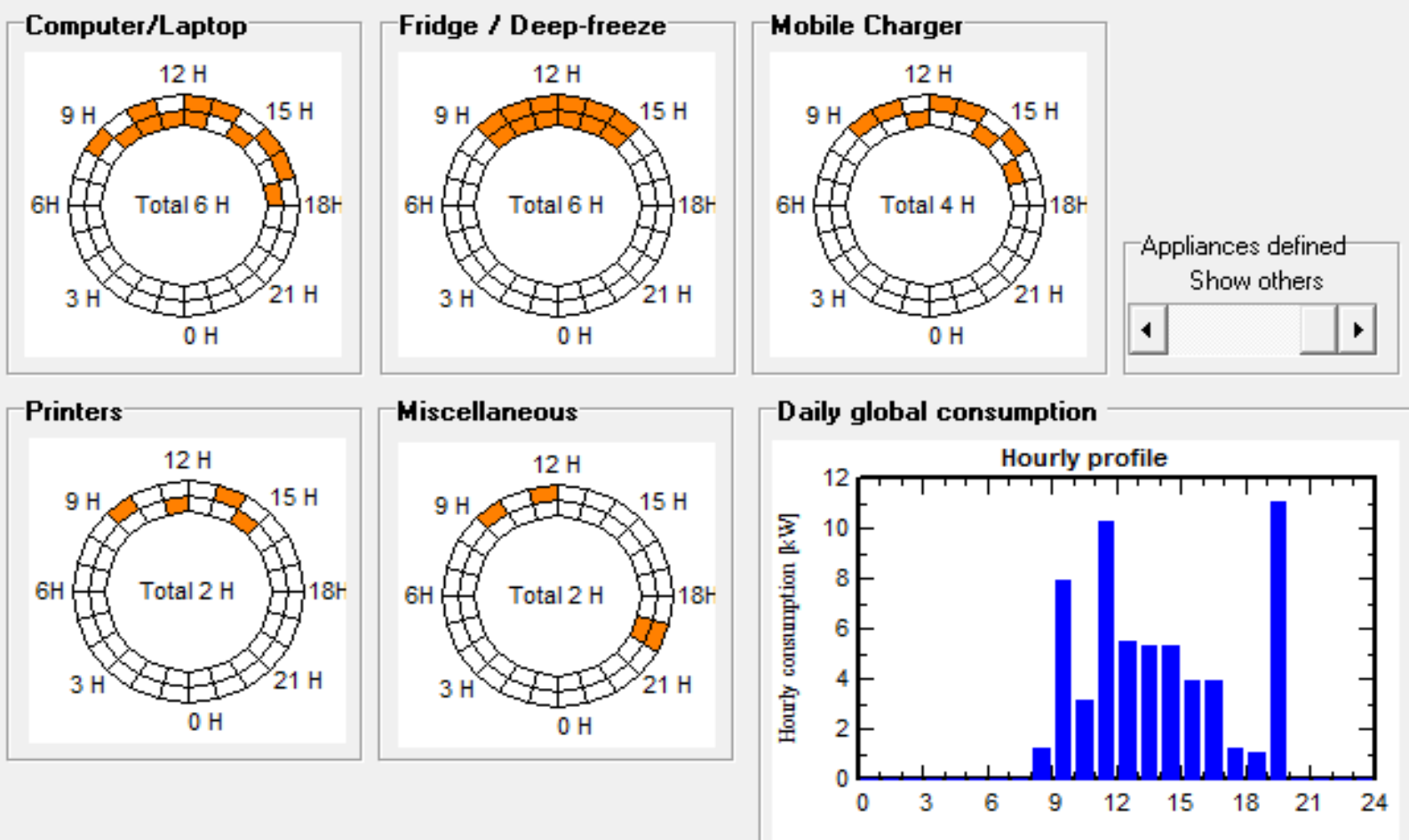

Figure 4. Hourly Load Distribution.

Figures 3 and 4 explain how the load in the faculty are distributed during use. In figure 4, the energy bulbs are switched on between the hours of 6-8 pm, the ceiling fans are in use between 11 am-5 pm, desktop computers, fridges, and mobile chargers are also distributed in certain hourly proportions. The same distribution also applies to fractions of values of daily energy extracted from the annual value of a 24-hr timeline. The results were generated by the software after load values have been inputted into it and the simulation is done. Days of autonomy fixed for the system is 5-days 


\section{Normalized productions (per installed kWp): Nominal power $19.80 \mathrm{kWp}$}

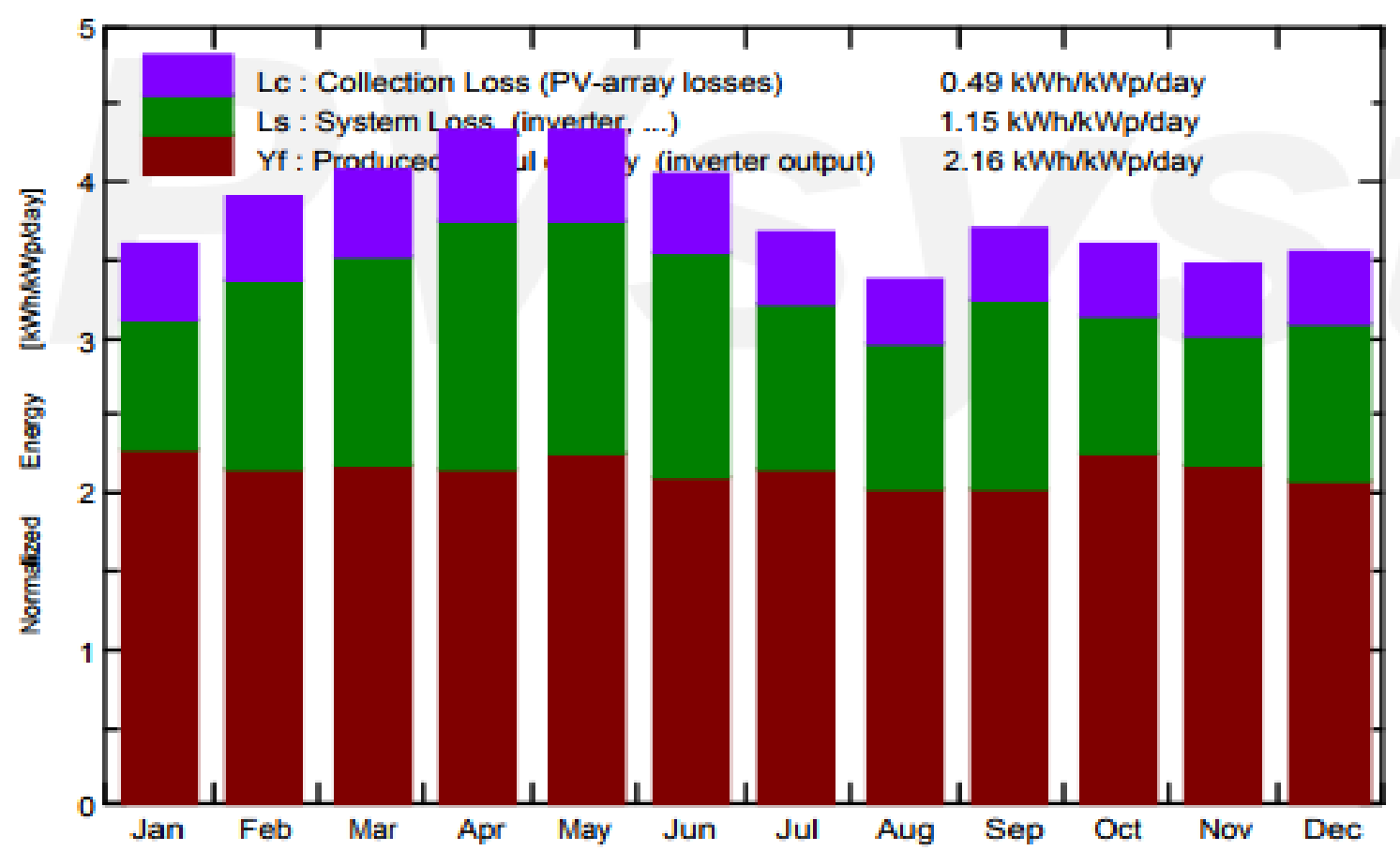

Figure 5. Normalized Energy Production.

In the chart in figure 5 , it shows the normalized ( $\mathrm{kWh} / \mathrm{kWp} / \mathrm{day})$ energy plotted against the months of the year to give a response of Collection loss Lc depicted with purple-colored bars with value $0.49 \mathrm{kWh} / \mathrm{kWp} /$ day, System losses (inverter...) and battery charging Ls depicted in green color with value $1.15 \mathrm{kWh} / \mathrm{kWp} /$ day and the produced energy (inverter output) $\mathrm{Yf}$ is depicted in red-colored bars with a $2.16 \mathrm{kWh} / \mathrm{kWp} /$ day value.

\section{CONCLUSION}

The PV system produces energy of 22.76MWh/year and supplies energy of 15.59MWh/year. It, therefore, illustrates PV system power produced to be greater than energy proffered as well as the energy need of the user. This draws to close that, User energy (load) capacity is met and exceeded in the system production. Excess unused energy of 5.608MWh/year (considering losses) noticed, is the disparity in energy values of the system and that of the user. With this result, the software calculates the performance ratio of the system at $56.71 \%$. The system can sustain itself for a period of 25 to 30 years or more if operated within its calculated energy limits. This solar photovoltaic system safes income as it reduces the electricity bill.

In conclusion, the system designed meets the major basic desired objective of this work and surpasses its design expectations. 


\section{RECOMMENDTIONS}

It is recommended that this design should be adopted when plans for a solar photovoltaic system has been drawn.

Also, for the solar photovoltaic system to serve for its appraised lifespan as proposed, it should be used on loads listed in this work, and appliances with thermostat properties should not be utilized on it if not calculated in the energy requirements during a redesigning or expansion phase.

\section{ACKNOWLEDGMENT}

The authors would like to acknowledge thankfully the continuous support by the Head of the Department of Electrical/ Electrical Engineering University of Port Harcourt as well as the entire member of the staff

\section{REFERENCE}

[1] A. Al-Salaymeh, Z. Al-Hamamre (2010) Technical and Economic Assessment of the utilization of Photovoltaic systems in residential buildings: The Case Study of Jordan. Journal of Energy Conversion and Management, August 2010.

[2] C.O.C Oko et al, (2012) Design and Economic Analysis of a Photovoltaic System: A Case Study. International Journal of Renewable Energy Development 1(3) 2012:65-73

[3] D. H. Li, K. L. Cheung, Tony N. T. Lam, Wilco Chan, (2012) A Study of grid-connected photovoltaic (PV) system in Hong Kong. Article in Applied Energy, Feb 2012, pp 90(1).

[4] El-Tallamy, A. Elbaset, (2016) Design and Power Quality Improvement of Photovoltaic Power System. http://www.springer.com>book, 2006.

[5] F. Agai, N. Caka, V. Komoni, (2015). Design Optimization and simulation of buildings in South East Europe. International Journal of Advances in Engineering and Technology, 2011, Vol 1, issue (5), pp 58-68

[6] J. Samimi, E.A. Soleimani, (2015) Optimal Sizing of photovoltaic System in varied climates. Journal of Solar energy 60(2):97-107.Feb 2015

[7] J.C. Hernandez, P. G. Vidal, G. Almonacid, (2010) Photovoltaic in grid-connected buildings. Sizing and Economic Analysis. International Journal of Renewable Energy 15(1):562-565, Sept 2010

[8] L. Fagbile, (2010) Estimation of Total Solar Radiation in Nigeria using meteorological, Nigeria. Journal of Renewable Energy 1. 2010, pp. 1-10.

[9] N. Boullosa. A little background on Solar power. January 2008, https://faircompanies.com

[10] O. W. Westbrook, F.D. Collins, (2013) Energy Model Validation for Large-Scale Photovoltaic systems. In Photovoltaic Specialists Conference (PVSC), 2013 IEEE 39. Pp.0830-0835

[11] W. Muneer, K. Bhattacharya, C. A. Canizares, (2011) Large-Scale Solar PV Investment Models, Tools, and Analysis: The Ontario Case. IEEE Transactions on Power Systems. December 2011, 26(4): pp. 2547-2555 